\title{
TÜRKÇEDE ÖKSÜZ VE YETIMM ÇOCUKLARLA İLGİLİ SÖZLER
}

\section{Okan Celal GÜNGÖR*}

Geliş Tarihi: Ocak, 2016

Çocuğun sağlıklı bir birey olarak yetişmesinde ve topluma kazandırılmasında, toplumun çekirdeğini teşkil eden kurum olarak ailenin dolayısıyla ebeveynlerin rolü yadsınamaz. Bir çocuğun yaşayabileceği en büyük acılardan biri hiç şüphesiz anne ve baba şefkati, sevgisinden uzak öksüz ve yetim büyümektir.

Orhun Abideleri'nde annesiz anlamılla bir at için kullanılan öksüz ve ilk İslami eserlerden itibaren kullanılan Arapça yetim karşılığ Türkçenin tarihî metinlerinde, başta atasözleri olmak üzere sözlü kültür ürünlerinde ve Anadolu ağızlarında pek çok kullanım mevcuttur. Çalışma kavramsal ve yapısal inceleme olmak üzere iki kısımdan oluşmaktadır. Kavramsal inceleme kısmında bu kullanımlar hem tematik olarak hem de dönem ve saha açısından tasnif edilirken, yapısal inceleme kısmında ifadeler kelime, kelime grubu ve cümle düzeyindeki birlikler olarak ayrılmıştır.

Anahtar Sözcükler: Öksüz, yetim, çocuk, söz varlığı.

\section{VOCABULARY RELATED MOTHERLESS AND FATHERLESS CHILDREN AT TURKISH}

\begin{abstract}
The role of family, constituting the core of society and thereby parents can not be ignored in raising a healthy child to grow into adults and integrate them into the society. One of the biggest tragedya child may suffer is to grow up with the lack of parental love and affection.

Orphan, which was used to describe a hourse in Orhun Monuments and a person whose father and mother died in early İslamic works has a lot of uses in historical Turkish texts, mostly in proverbs, in oral culturel Works and in Anatolian dialects.

This study consist of two conceptual and structural parts. While the material in conceptual study is classified in terms of both theme and period and field, expressions are divided into word, word group and sentences.
\end{abstract}

Keywords: Motherless, fatherless, child, vocabulary.

\section{Kavramsal İnceleme}

$\mathrm{Bu}$ bölümde, Türkçenin tarihî metinlerinin, dönem sözlüklerinin, Güncel Türkçe Sözlük'ün, başta atasözleri ve deyimler olmak üzere sözlü kültür ürünlerinin, konuyla ilgili doğrudan ya da dolaylı yapılmış çalışmaların taranması sonucu elde edilen malzeme hem tematik olarak hem de dönem ve saha açısından tasnif edilip değerlendirilecektir.

\footnotetext{
* Dr.; Millî Eğitim Bakanlığı, okancelalgungor@ hotmail.com.
} 


\section{1. Öksüz ve Yetim Çocuk}

İlk kez Orhun Abideleri’nde “kül tig(i)n: ögs(ü)z (a)kin: bin(i)p: tokuz (e)r(e)n: $s(a) n c ̧ d \imath^{\prime \prime 1}$ şeklinde annesiz anlamılla bir at için kullanılan $\ddot{o k s} \ddot{u} z^{2}(<\ddot{o g}+s \ddot{u} z)$ kelimesi, Divânü Lugâti’t Türk’te "yetim, şaşkın” anlamında kullanılmıştır. Türkiye Türkçesi ağızlarında “ögsüz / öksüs / ösgüz / ösüz / ōsüz"," şeklinde annesi olmayan çocuk, öksüz biçiminde "anlayışsız", anlamında, çağdaş Türk lehçelerinden "Azerbaycan Türkçesinde yetim, Başkurt Türkçesinde yitim ve ükhiz, Kazak Türkçesinde jetim, Kırgız Türkçesinde cetim, enesi ölgön, Tatar Türkçesinde yätim ve üksiz, Türkmen Türkçesinde yetim, Özbek Türkçesinde yetim, Uygur Türkçesinde jitim, ", şeklinde daha çok yetim (babası ölen çocuk) karşılığında kullanılan kelime bugün Türkçe Sözlük'te annesi veya hem annesi hem babası ölmüş olan (çocuk), kimsesiz (kişi) ${ }^{6}$ olarak geçer. İlk İslami eserlerden itibaren babası ölmüş çocuk anlamında kullanılan Arapça yetim $^{7}$ kelimesi bugün Türkçe Sözlük'te de babası ölmüş (çocuk) olarak tanımlanmaktadır ${ }^{8}$.

Öksüz ve yetim kelimeleri dışında yazılı metinlerimizde ve Anadolu ağızlarında bu bağlamda kullanılan çeşitli sözler vardır. Annesi ölen çocuk için Osmanlı Türkçesi döneminden

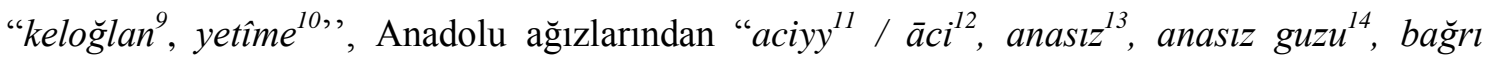
geçik $^{15}$, duluğu sirkeli ${ }^{16}$, milcan ${ }^{17,}$, sözleri, babası ölen çocuk için Göktürkçe ve Uygurca döneminden "kañsız ${ }^{18}$ (> hañsız) ${ }^{19}$ ", Harezm Türkçesi döneminden “atasız ${ }^{20,}$, Osmanlı

\footnotetext{
${ }^{1}$ Bu ibarenin okunuşu tartışmalıdır. Talat Tekin tarafından "Kül Tigin öksüz kır (at)ına binip dokuz er(i) mızrakladı" (Tekin, 2010: 38) H. N. Orkun tarafından ise "Kül Tigin öksüz [denilen] akına binip dokuz eri mızrakladı"' şeklinde okunmuştur (Orkun I, 1987: 50).

2 Öksüz kelimesi Ercilasun ve Akkoyunlu tarafından "yetim, şaşkın”'(Ercilasun ve Akkoyunlu, 2014: 42); Besim Atalay tarafından "şaşkın, akılsız, anlayışsız" (Atalay I, 2006: 96); Dankoff ve Kelly tarafından "şaşkın, hayran" şeklinde okunmuştur (Dankoff ve Kelly, 1984: 45).

${ }^{3}$ Türk Dil Kurumu, Türkiye'de Halk Ağzindan Derleme Sözlüğ̈̈, C. V. TDK Yay. Ankara (1963-1982) s. 3356.

${ }^{4}$ Türk Dil Kurumu, age., C. V. s. 3326.

${ }^{5}$ Ahmet B. Ercilasun ve diğerleri, Karşılaştırmalı Türk Lehçeleri Sözlüğü, Kültür Bakanlı̆̆ı Yay. Ankara, 1991, s. 676.

${ }^{6}$ Türk Dil Kurumu, Türkçe Sözlük, TDK Yay. Ankara, 2011, s. 1843.

${ }^{7}$ Reşit Rahmeti Arat, Kutadgu Bilig I (Metin), TDK Yay. Ankara, 2007, s.166.

${ }^{8}$ Türk Dil Kurumu, Türkçe Sözlük, TDK Yay. Ankara, 2011, s. 1843.

${ }^{9}$ Paşa Yavuzarslan, Şemsettin Sami Kamus-ı Türkî, TDK Yay. Ankara, 2010, s.166

${ }^{10}$ Ferit Devellioğlu, Osmanlıca-Türkçe Ansiklopedik Lûgat, Aydın Yay. Ankara, 2008, s. 1161.

${ }^{11}$ Üzeyir Köse, İslam Hukuku Açısından Kimsesiz Çocukların Korunması ve Bakımı, Basılmamış Yüksek Lisans Tezi, Kahramanmaraş, 2008, s. 15.

${ }^{12}$ Türk Dil Kurumu, age., C. I. s. 54.

${ }^{13}$ Semih Tezcan ve Hamza Zülfikar, Nehcü'l-Ferādìs I (Cennetlerin Açık Yolu), TDK Yay. Ankara, 2004, s. 54.

${ }^{14}$ Emir Kalkan, Afşar Ağıtları, Kayseri Büyükşehir Belediyesi Yay. Ankara, 1998, s. 259.

${ }^{15}$ Türk Dil Kurumu, age., C. VI. s. 4442.

${ }^{16}$ Türk Dil Kurumu, age., C. VI. s. 4442.

${ }^{17}$ Türk Dil Kurumu, age., C. IV. s. 3199.

${ }^{18}$ H. Namık Orkun, Eski Türk Yazıtlarl, C. III. TTK Yay. Ankara, 1987, s. 61.

${ }^{19}$ Ahmet Caferoğlu, Eski Uygur Türkçesi Sözlüğ̈̈, TDK Yay. Ankara, 2011, s. 81.
} 
Türkçesi döneminden "bî-peder ${ }^{21}$,, Türkiye Türkçesi yazı dilinden "babasız", saçı bitmedik $(\text { yetim })^{23}$, tüyü bitmedik (yetim) ${ }^{24,}$, Anadolu ağızlarından "başsız" ${ }^{25}$, dulaz $^{26}$, gebedek $^{27}$, merdesiz ${ }^{28}$, mesek $^{29}$, tay $^{30}$, tumbat $^{31}$, annesi ya da babası veya her ikisi de ölen çocuk için ise Harezm Türkçesi döneminden "atasız anasız" ${ }^{32}$,, Anadolu ağılarından “cebedak ${ }^{33}$, çoma ${ }^{34}$, ekti ${ }^{35}$, gebe $^{36}$, hort $^{37}$, hortlu / hörtlï̈ ${ }^{38}$, irik $^{39}$, kesit $^{40}$, kopel $^{41}$, övbet ${ }^{42}$ persin $^{43}$, segir $^{44}$, sevi $^{45}$, teberik $^{46}$,', Osmanlı Türkçesi döneminden "latîm ${ }^{47}$, yetîmü't-tarafeyn ${ }^{48,}$, Türkiye Türkçesi yazı dilinden ise "yuvasız kuş̧̧uk ${ }^{49,}$, sözü tespit edilmiştir. İfadeler içerisinde sadece Arapça yetîme kelimesi Türkçede cinsiyet ifade eder ve babası ölmüş kızı karşılar.

Öksüz ve yetim kavramları karşıllı̆̆ kullanılan ifadelere bakıldığında "anasız guzu, yuvasız kuş̧̧uk" sözlerinde annesi olmayan çocuk kuzuya, hem annesi hem de babası olmayan çocuk yuvasız kuşa benzetilirken, "keloğlan" sözünde kimsesiz bir masal kahramanı, öksüz çocuğu karşılamaktadır. "Saçı bitmedik, tüyü bitmedik (yetim)" sözleri, çocuğun biyolojik gelişimiyle ilgili olup daha bebeklik döneminde yaşanan durumla, organ adı bağır sözcüğünün

\footnotetext{
${ }^{20}$ Tezcan ve Zülfikar, age., s. 58.

${ }^{21}$ Mertol Tulum, XVII. Yüzyll Türkçesi ve Söz Varlı̆̆ı, TDK Yay. Ankara, 2011, s. 432.

${ }^{22}$ Türk Dil Kurumu, Türkçe Sözlük, s.221.

${ }^{23}$ Mehmet Hazar, "Türk Dilinde Çocuk ve Genç", II. Ulusal Çocuk ve Gençlik Edebiyatı Sempozyumu Gelişmeler, Sorunlar ve Çözüm Önerileri (04-06 Ekim 2006), Ankara Üniversitesi Eğitim Bilimleri Fakültesi Yayınları, Ankara 2007, s. 249-278

${ }^{24}$ Adnan Rüştü Karabeyoğlu, "Fiillerin Kılınış Hususiyetleri ve -DIk /- DUk İyelik Ekinin Mastar
} İşlevi', Turkish Studies, C. VI. S. 4. 2011, s. 649-658.

${ }^{25}$ Türk Dil Kurumu, age., C. VI. s. 4450.

${ }^{26}$ Türk Dil Kurumu, age., C. II. s. 1596.

${ }^{27}$ Türk Dil Kurumu, age., C. III. s. 1955.

${ }^{28}$ Türk Dil Kurumu, age., C. IV. s. 3167.

${ }^{29}$ Türk Dil Kurumu, age., C. IV. s. 3172.

${ }^{30}$ Türk Dil Kurumu, age., C. V. s. 3852.

${ }^{31}$ Türk Dil Kurumu, age., C. V. s. 3993.

${ }^{32}$ Suat Ünlü, Harezm Altınordu Türkçesi Sözlüğü, Eğitim Yay. Konya, 2012, s. 70.

${ }^{33}$ Türk Dil Kurumu, age., C. II. s. 871.

${ }^{34}$ Türk Dil Kurumu, age., C. II. s. 1264.

${ }^{35}$ Türk Dil Kurumu, age., C. VI. s. 4230.

${ }^{36}$ Türk Dil Kurumu, age., C. III. s. 1964.

${ }^{37}$ Türk Dil Kurumu, age., C. III. s. 2414.

${ }^{38}$ Türk Dil Kurumu, age., C. III. s. 1964.

${ }^{39}$ Türk Dil Kurumu, age., C. IV. s. 2550.

${ }^{40}$ Türk Dil Kurumu, age., C. IV. s. 2766.

${ }^{41}$ Türk Dil Kurumu, age., C. III. s. 2114.

${ }^{42}$ Türk Dil Kurumu, age., C. V. s. 3363.

${ }^{43}$ Türk Dil Kurumu, age., C. V. s. 3434

44 Türk Dil Kurumu, age., C. VI. s. 4679.

${ }^{45}$ Türk Dil Kurumu, age., C. V. s. 3596.

${ }^{46}$ Türk Dil Kurumu, age., C. V. s. 3857.

${ }^{47}$ Köse, age., s. 15.

${ }^{48}$ Hakan Aytekin, 1914-1924 Yılları Arasında Korunmaya Muhtaç Çocuklar ve Eğitimleri, Basılmamış Yüksek Lisans Tezi, İstanbul, 2006, s. 1.

${ }^{49}$ Bedri Aydoğan, "Mehmet Emin Yurdakul'un Çocuk Şiirleri', Çukurova Üniversitesi Sosyal Bilimler Enstitüsü Dergisi, C. 19. S. 2. 2010, s. 127. 
"bağrl geçik" şeklinde kullanımı yaşanan acıyla ve kimsesizlik hâliyle, baş sözcüguünün "başsız" şeklinde kullanımı ise babanın ailenin temel direği, büyüğü olarak algılanmasıyla ilintilidir. Annesi ve babası olmayan çocuğu karşılamak için anne ve baba anlamındaki kelimelere $+s ı z$ olumsuzluk eki getirilerek “anasız, atasız, atasız anasız, babasız" ş̧eklinde yapılar da oluşturulmuştur.

\section{2. Öksüz ve Yetim Kalma, Bırakma}

Öksüz ve yetim kalma, bırakma durumu için Karahanlı Türkçesi döneminden "anasız kalmak $^{50}$, öksüz bolmak / öksüz olmak ${ }^{51}$ ", Harezm Türkçesi döneminden "öksüz kllmak",52, Eski Anadolu Türkçesi döneminden “öksüz eylemek ${ }^{53}$,, Çağatay Türkçesi döneminden “yetim bolmak / yetim olmak ${ }^{54,,}$, Türkiye Türkçesi yazı dilinden “öksüz kalmak ${ }^{55}$, öksüzlük

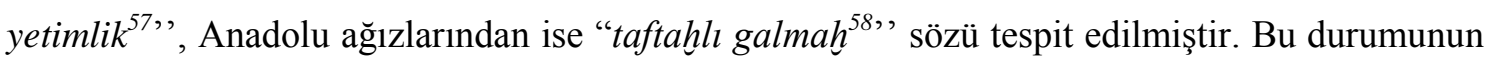
ifadesinde bol-, eyle- kll-yardımcı fiilleri dışında öksüz ve yetim kelimelerine $+l \imath k$ isimden isim yapan ekin getirildiği görülmektedir.

Öksüz ve yetim kalma durumuyla ilgili bazı kullanımlar ise ilenç mahiyetindedir. "Balaların ardında kala"; Balaların ardinda meleye ${ }^{60}$; Ölesin yavrular arkanda kala"; Yavruların yetim kala ${ }^{62}$; Yuvada çocuğu kalsın ${ }^{63}$, , ifadeleri, anne ve babaya, diğerleri ise çocuğa hitaben söylenmiştir. Bunlar içerisinde "Anadan yetim olasın"; Anan öle ; Ananın lokması ağzına ola ${ }^{66}$; Anasız kal e mi $?^{67}$; anasız kalasıca ${ }^{68}$; Anasız kalasın ${ }^{69}$; Benim gibi öksüz

${ }^{50}$ Aysu Ata, Kııșașü'l-Enbiyā I, TDK Yay. Ankara, 1997, s. 262.

${ }^{51}$ Ata, age., s.57.

${ }^{52}$ Tezcan ve Zülfikar, age., s. 64.

${ }^{53}$ Muhammed Yelten, Şirvanlı Mahmud, Târih-i İbn-i Kesîr Tercümesi (Giriş-İnceleme-Metin-Sözlük), TDK Yay. Ankara, 1998, s. 153.

${ }^{54}$ Z. Kargı Ölmez, Ebulgazi Bahadır Han, Şecere-i Terākime (Türkmenlerin Soy Kütüğü), Simurg Yay. Ankara, 1996, s. 222.

${ }^{55}$ Türk Dil Kurumu, Türkçe Sözlük, s. 1842.

${ }^{56}$ Türk Dil Kurumu, Türkçe Sözlük, s. 1843.

${ }^{57}$ Türk Dil Kurumu, Türkçe Sözlük, s. 2584.

${ }^{58}$ Türk Dil Kurumu, age., C. V. s. 3801.

${ }^{59}$ Halil Ersoylu, Türk Dilince Dualar Beddualar Sözlüğ̈̈, Ötüken Neşriyat, Ankara, 2012, s.167.

${ }^{60}$ Ersoylu, age., s.167.

${ }^{61}$ Doğan Kaya, Folklorumuzda Beddua Söyleme Geleneği ve Türk Halk Şiirinde Beddualar, AKDTYK Yay. Ankara, 2001, s. 140.

${ }^{62}$ Ersoylu, age., s. 346.

${ }^{63}$ Ersoylu, age., s. 353.

${ }^{64}$ Ersoylu, age., s. 135.

${ }^{65}$ Serdar Bulut, "Anadolu Ağızlarında Kullanılan Kalıp Sözler ve Bu Kalıp Sözlerin Kullanım Özellikleri'”, Turkish Studies, C. 7. S. 4. 2012, s.1135.

${ }^{66}$ Ersoylu, age., s. 156.

${ }^{67}$ Çiğdem Erol, Türkiye Türkçesinde Kalp Sözler Üzerine Bir İnceleme, Basılmamış Yüksek Lisans Tezi, İstanbul, 2007, s. 135.

${ }^{68}$ Erol, age., s. 136.

${ }^{69}$ Ersoylu, age., s. 156. 
kalasın $^{70}$; Öksüz kalasın da beni anasın" ${ }^{71,}$ sözleri annenin kaybı, "Allah'tan umarım baban öle ${ }^{72}$; Baba yüzü görmeyesin ${ }^{73}$; Baban öle ${ }^{74}$; Babanın başucuna oturasin ${ }^{75}$; Babanın lokmasl ağzına ola ${ }^{76}$; Yetim kalasın ${ }^{77,}$, sözleri babanın kaybı üzerinedir. Her ikisinin birden kaybı ise “Anadan babadan ol ${ }^{78}$; Anan baban bir klzll tabutta gide ${ }^{79}$; Anan baban tünbe tünbe ola ${ }^{80}$; anasız, babasız kalasıctk ${ }^{81}$; ellerde illerde kalast ${ }^{82}$, ellere kalasi $^{83}$, ellere kalasıca ${ }^{84,}$ kullanımlarına yansımıştır. "Meleşmek ${ }^{85 ،}$, fiili ise yetim kalan çocukların ağlamaları için kullanılır.

\section{3. Öksüz ve Yetim Hakkı Yeme, Öksüzün Ahını Alma}

Türk Kültüründe ve İslam dininde kimsesiz çocukların korunup gözetilmesi, toplumsal yaşama kazandırılması, evlenip yuva kurmalarına yardımcı olmak esastır. Bu çocukların hakkını gasp edenlerin bir şekilde hem bu dünyada toplumun hem de ahirette Allah'in huzurunda yerlerinin olmayacağı inancı hâkimdir. Bu inanç "Öksüzün ahı pakçe gelir, yapça kakar ${ }^{86}$; Yetim hakkl, yedi taşı deler de geçer $^{87}$; Yetim mall, ateşten gömlektir ${ }^{88}$, Yetim malı gasp edene, hakikât yolu kapalı olur ${ }^{89}$; Yiyeceklerin en kötüsü, yetim mall yemektir ${ }^{90,}$, sözleriyle dile getirilmiştir. Öksüzün ahını alanların cezasız kalmayacakları düşüncesi ise şeytan örneğiyle “Öksüzün şeytanı çok olur ${ }^{91}$; Öksüzün şeytanı dokuz olur ${ }^{92, "}$ kullanımlarına yansımıştır.

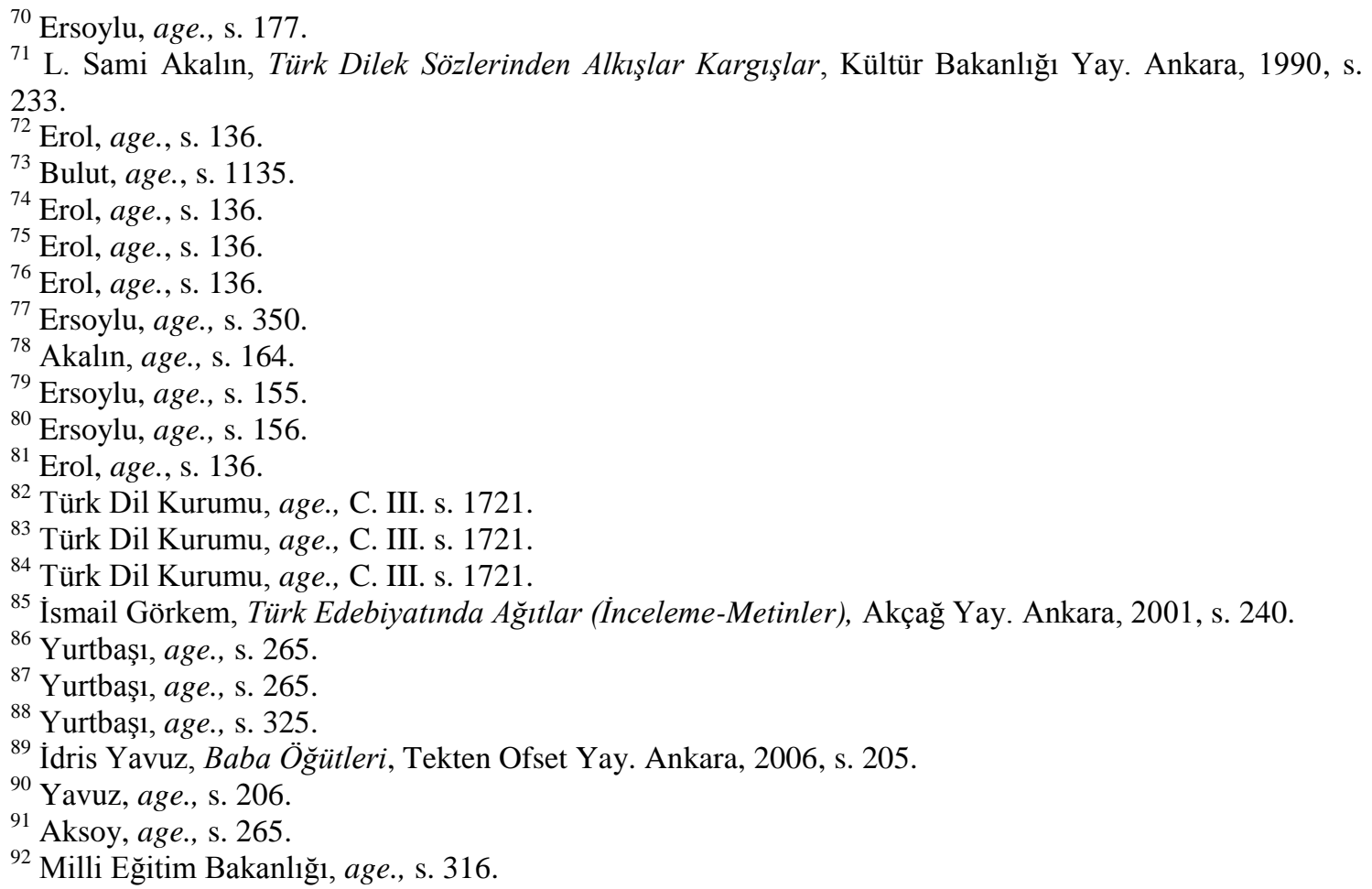




\section{4. Öksüz ve Yetimi Koruyup Gözetmenin Gereği}

Yetim ve kimsesiz çocuklara sahip çıkan, merhametli kimseler için “öksüz anası", öksüz babası ${ }^{94}$, öksüzler babası, anası ${ }^{95,}$, ifadeleri kullanılmaktadır. "Oğlun gibi ever, kızın gibi gelin $e t^{96,}$, sözünde, öksüz çocuğu kendi evladın gibi görme algısı yansitılırken, "Yolsuzu yola getirmek, öksüze kaftan giydirmek gibidir ${ }^{97}$; Zalime haddini bildirmek, öksüze kaftan biçmek gibidir $^{98,}$ sözlerinde bir tür benzetmeyle öksüzü giydirip kuşatmanın önemi üzerinde durulmuştur.

\section{5. Öksüz ve Yetimin Korunup Gözetilmemesi}

Annesi ve babası olmayan çocuk, toplumsal yaşamda hem maddi hem de manevi pek çok zorluğu kendi göğüslemek durumundadır. Koruyup kollayanı olmadığı için öksüzün hem fizikî hem de psikolojik olarak hırpalanacağı, rencide olacağı düşüncesi “Alçak eşek binmeye kolay, öksüz çocuk dövmeye kolay ${ }^{99}$; Öksüz ölmez, örselenir ${ }^{100,}$, şeklinde ifade edilmiştir. Öksüz, yetim çocuğun maddi imkânsızlıklardan dolayı yeteri kadar beslenememe durumu “Öksüz kuzu toklu olmaz ${ }^{101}$; Öksüz kuzu toplu olmaz ${ }^{102}$; Öksüzün bir doyarl ayran, bir doyarı bayram $^{103}$; Öksüzün dokuz karnı olur, birisi (sekizi) doyar, sekizi (biri) aç gezer ${ }^{104}$; Öksüzün karnı doymaz ${ }^{105}$; Öksüzün öğ̈̈nü birdir ${ }^{106}$; Yetim kuzu koç olmaz ${ }^{107,,}$ şeklinde, öksüze yapılacak yardımın öncelikle beslenmesine yönelik olması gerektiği düşüncesi “Öksüz doyur da ne yapacă̆ına karışma ${ }^{108}$; Öksüz kır köpeği neyler ${ }^{109,}$, şeklinde ifade edilmiştir. "Öksüze acır çok ama ekmek verir yok ${ }^{110}$; Öksüzü kayıran çok, yarım ekmek veren yok ${ }^{111}$; Öksüzü seven çok olur amma eline beş para veren olmaz ${ }^{112}$; Öksüzün camide babası, hamamda anası çok olur ${ }^{113}$;

\footnotetext{
${ }^{93}$ Türk Dil Kurumu, Türkçe Sözlük, s. 1843.

94 Türk Dil Kurumu, Türkçe Sözlük, s. 1843.

${ }^{95}$ Yavuzarslan, age., s. 943.

${ }^{96}$ Yavuzarslan, age., s. 139.

${ }^{97}$ Yavuzarslan, age., s. 487.

${ }^{98}$ Milli Eğitim Bakanlığı, Türk Ata Sözleri ve Deyimleri II, MEB Yay. İstanbul, 1971, s. 316.

99 Ömer Asım Aksoy, Atasözleri ve Deyimler Sözlüğ̈̈ I: Atasözleri Sözlüğü, TDK Yay Ankara, 1971, s. 125.

${ }^{100}$ Yurtbaş1, age., s. 266.

101 Aksoy, age., s. 329.

${ }^{102}$ Yurtbaş1, age., s. 266.

103 Yurtbaş1, age., s. 266.

${ }^{104}$ Yurtbaş1, age., s. 266.

105 Milli Eğitim Bakanlığı, age., s. 316.

${ }^{106}$ Milli Eğitim Bakanlığı, age., s. 266.

${ }^{107}$ Milli Eğitim Bakanlığ 1 , age., s. 266.

${ }_{108}$ Milli Eğitim Bakanlığ 1 , age., s. 265.

${ }^{109}$ Yurtbaş1, age., s. 266.

${ }^{110}$ Milli Eğitim Bakanlığ1, age., 316.

111 Yurtbaş1, age., s. 265.

112 Yurtbaş1, age., s. 265.

113 Yurtbaş1, age., s. 266.
} 
Yetime acıyan çok olur da bir dilim ekmek veren bulunmaz ${ }^{114}$; Yetime gel gel diyen çok da çörek veren olmaz ${ }^{115,}$, gibi örneklerde ise kutsal mekânlarda, kalabalık ortamlarda öksüz, yetim çocuğa acıyan çok olsa da gerçekte ihtiyacını karşılayan insanların olmadığı düşüncesinin bir yansımasıdır. "Öksüzün büyü̈̆̈̈nü döverler ${ }^{116, "}$ sözü, çocukken ve yetişkinken öksüz kalan kişilere yönelik toplumun bakış açısındaki farklılı̆̆ yansıtırken, öksüz çocuğun karşılaşacağı sorunlarla bizzat baş etmek zorunda kalacağı, öksüze kimsenin destekçi olmadığı düşüncesi “Öksüz kendi göbeğini kendi keser ${ }^{117}$; Öksüze vurmuşlar, vay anam, demiş ${ }^{118}$; Öksüzü dövmüşler, vay arkam, demişs ${ }^{119}$; Öksüzün karnına vurmuşlar, vay arkam, demişs ${ }^{120,}$, şeklinde ifade edilmiştir.

\subsection{Sevgisiz, Mutsuz ve Bahtsız Büyüme}

Annesiz büyüyen, onun sevgisinden mahrum kalan çocuğun bu eksikliği ömür boyu yüreğinde hissedeceği düşüncesi “Anadan öksüz, babadan yetim kalanın yüreği (strtı) yăg bağlamaz ${ }^{121}$; Anam olsa da taştan olsa ${ }^{122}$; Anam olsun da duvara ăg kursun ${ }^{123}$; Anasız kuzu melemez $^{124}$; Öksüz büyür büyür küçülür ${ }^{125}$; Öksüz çocuğun bă̆rında yă̆ olmaz ${ }^{126}$; Öksüzün bağrı yanık, gözü sönük olur ${ }^{227}$; Öksüzün başı yerde gerek ${ }^{128,}$, sözleriyle dile getirilirken, babasız büyümekten kaynaklı mutsuzluk "boynu buruk ${ }^{129,}$, deyimine yansımıştır. "Analı oğlak (kuzu), yarda (gökte) oynar (gezer); anasız oğlak (kuzu), yerde oynar (gezer) ${ }^{130,, ~ s o ̈ z u ̈ ~ i s e ~ a n n e ~}$ sevgisiyle büyüyen çocuğun mutluluğunu davranışlarıyla belli edeceği ve özgüveninin yüksek olacağ düşüncesiyle ilgilidir. Öksüz ve yetim çocuğa hayatta talihin hiç gülmediği yönündeki algının ise "Öksüz güler mi gülerse onar mı $?^{131}$; Öksüz güler mi meğer yanıla ${ }^{132}$; Öksüz hırsızlığa çıkarsa ay ilk akşamdan doğar ${ }^{133}$; Öksüz neden güler, yanılır da güler ${ }^{134}$; Öksüz

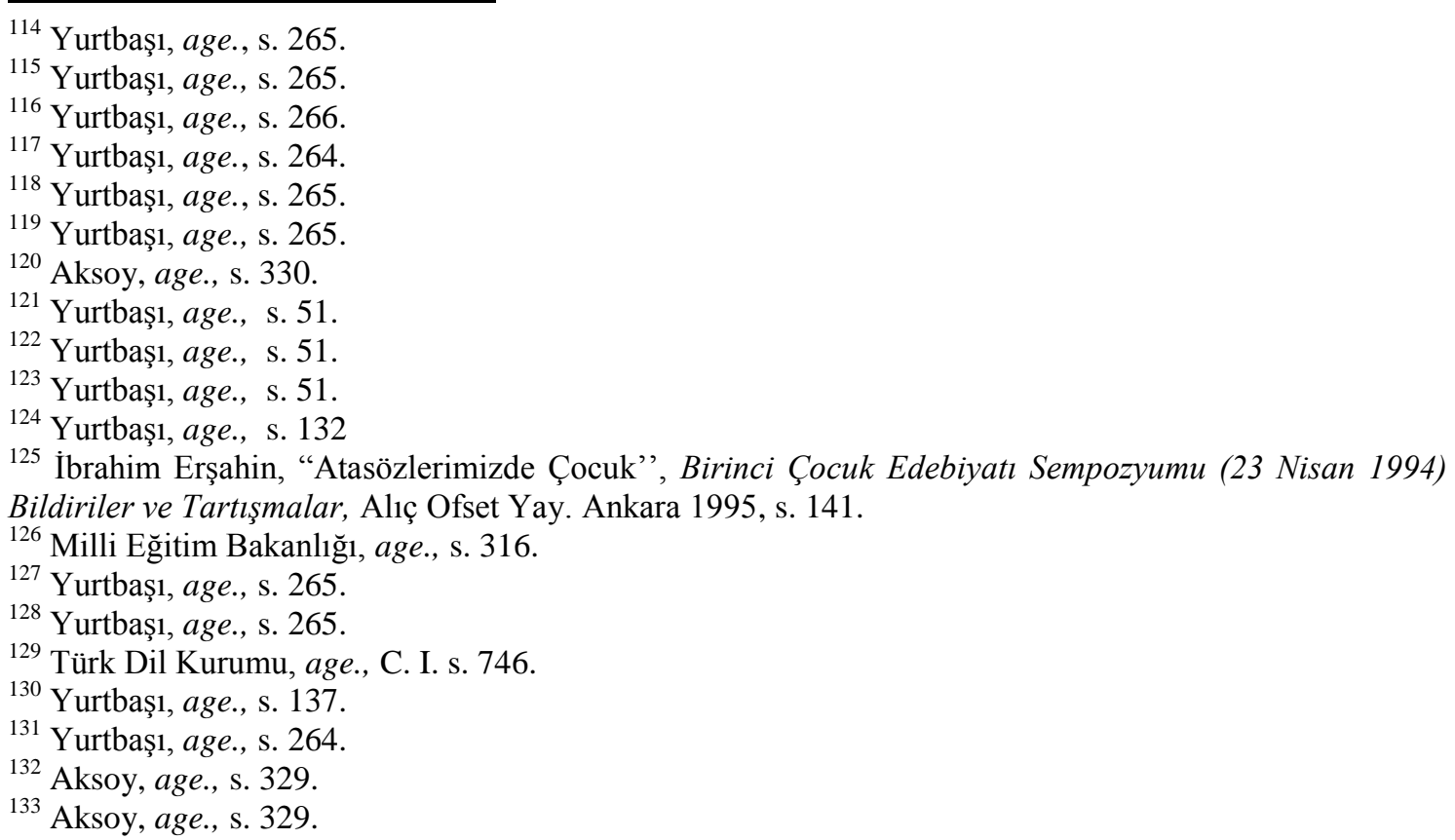


oynaşa çıkmış, ay akşamdan doğmuş ${ }^{135}$; Öksüz yemek bulsa burnu kanar ${ }^{136}$; Öksüze güldün mü demişler meğer uyurken demiş ${ }^{137}$; Öksüzün alnına güneş doğmaz ${ }^{138}$; Yetim büyür, felek utanır ${ }^{139}$; Yetim demiş: "Ben güldüm". Felek demiş: "Ben neredeydim? ${ }^{140,}$; Yetim güler, yanlış güler $^{141,}$, sözlerine yansıdığı görülmektedir.

$\mathrm{Bu}$ hususta tespit edilen diğer kullanımlar ise şunlardır: "Anasız çocuk evde çürür, babasız çocuk çarşıda ${ }^{142}$; Öksüzün nesi olur, memesiz de büyürr ${ }^{143}$, ,

\subsection{Terbiyeden Yoksun Büyüme}

Anne ve babasız büyüyen çocukların düzenli bir aile terbiyesi göremediğinden, anne ve babasının ilgi ve sevgisinden yoksun kaldığından dolayı aykırı davranışlar içerisine girebileceği, algısı, “Atasız uşak (evlat), yularsız eşek (gibidir) ${ }^{144}$; Yavşak büyür bit olur, öksüz büyür it olur $^{145,}$, şeklinde ifade edilmiştir. " $E k t i{ }^{146,}$, kelimesi de Anadolu ağızlarında anasız babasız büyüdügü için arsız olan kimseler için kullanılır.

\subsection{Babanın Annesizlikten Kaynaklanan Boşluğu Dolduramaması}

Annenin çocuğun yaşamındaki yeri çok farklıdır. Özellikle bebeklik döneminde annenin bebeğiyle kurduğu güvene dayalı duygusal ilişkiyi babanın kurması, aynı şefkati ve ilgiyi çocuğa gösterebilmesi mümkün değildir. Anne çocuk arasında kurulan bu duygusal ilişki, çocuğun gelecekteki yaşamında kuracağı ilişkilerin niteliğini de belirler. Babanın anne kadar çocuğun sorunlarıyla ilgilenmediği, anneye göre çocuğun sorunlarına daha duyarsız kaldığı evlenmişse de üvey annenin tesirinden kurtulamayacağı düşüncesi “Ana, analık olursa baba da babalık olur ${ }^{147}$; Ana ciğerden yana, baba dağda bir oba ${ }^{148}$; Ana üvey olunca baba gâvur olurmuş $^{149}$; Ana yüreği güveç gibi, baba yüreği bakır tencere gibi kaynarmış ${ }^{150}$; Anası

\footnotetext{
${ }^{134}$ Aksoy, age., s. 330.

135 Aksoy, age., s. 330.

${ }^{136}$ Milli Eğitim Bakanlığ

${ }^{137}$ Yurtbaş1, age., s. 266.

${ }^{138}$ Yurtbaş1, age., s. 265.

${ }^{139}$ Yurtbaş1, age., s. 265.

${ }^{140}$ Yurtbaş1, age., s. 266.

${ }^{141}$ Yurtbaş1, age., s. 266.

${ }^{142}$ Yurtbaş1, age., s. 51.

${ }^{143}$ Yurtbaş1, age., s. 265.

${ }^{144}$ Yurtbaş1, age., s. 486.

${ }^{145}$ Yurtbaş1, age., s. 265.

146 Türkiye’de Halk Ağzından Derleme Sözlüğü. C. IV. s. 2517.

${ }^{147}$ Ruhiye Eda Eser, Türk Masallarında Çocuk, Basılmamıș Yüksek Lisans Tezi, Elazı̆̆, 2000, s. 142.

${ }^{148}$ Yurtbaş1, age., s. 51.

${ }^{149}$ Yurtbaş1, age., s. 49.

${ }^{150}$ Yurtbaş1, age., s. 51.
} 
olmayanın babası olmaz ${ }^{151}$; Baba öksüzü, öksüz değil; ana öksüzü, öksüzdür ${ }^{152}$; Babası öksüz, yarım öksüz; anasız öksüz, gerçek öksü̈z ${ }^{153}$; Çiftli çubuklu babam olacağına, gümüs yüzüklü anam olsun ${ }^{154}$; Yüz koyunlu atam kalmaktan, bir yüksüklü anam kalmak yeğdir ${ }^{155}$, sözlerine yansımıştır.

\section{9. Öksüz Kalmakla Yetim Kalmanın Aynı Derecede Zor Oluşu}

Annesiz büyümeyle babasız büyümenin aynı derecede zor oluşu "Ha anan ölmüşs öksüzsün, ha baban ölmüş yetimsin ${ }^{156,,}$ şeklinde ifade edilmiştir.

\subsection{Hassas Bir Yüreğe Sahip Olma}

Annesiz büyüyen çocuğun nahif, ince ruhlu, hassas olacağı düşüncesi “Öksüzün yüreği yufka olur ${ }^{157}$, , şeklinde ifade edilir.

\subsection{Acı Sözler Söyleme}

Öksüz çocuğun annesizlikten kaynaklı, aşırı hassasiyetin tesiriyle etrafındaki insanlanı istemeden de olsa kırabileceği, sözlerinin başkalarına ağır gelebileceği düşüncesi “Analı kızın bedeni büyür, anasız kızın söz ${ }^{158}$; Eski tutun biti, öksüz oğlanın dili acı olur ${ }^{159}$, sözlerine yansımıştır.

\subsection{2. Öksüzün Kadir Kıymet Bilmemesi}

Kimsesiz çocuğun kendisine yapılan yardımlara, iyi niyete karşılık minnet duymaması,

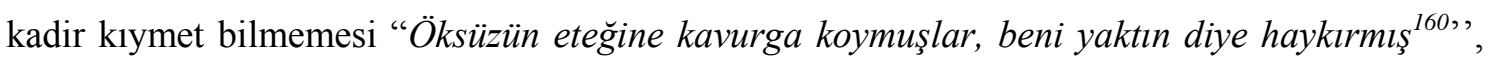
iyilik yapanlara karş1lık düşmanca tutumları ise "Öksüz besle hasmın olsun, karga besle gözün oysun $^{161,}$, şeklinde ifade edilmektedir.

\footnotetext{
${ }^{151}$ Yurtbaş1, age., s. 205.

152 Yurtbaş1, age., s. 49.

${ }^{153}$ http://iskilipliyiz.com/forum-oku-59272 oksuz_kimdir.html

154 Zafer İlbars, "Türk Toplumunda Çocuk Anlayışı ve Çocuğa Bakış" II. Ulusal Çocuk Kültürü Kongresi Bildirileri Cumhuriyet ve Çocuk (4-6 Kasım 1998), Ankara Üniversitesi Çocuk Kültürü Araştırma ve Uygulama Merkezi Yay. Ankara, 1999, s. 426.

${ }^{155}$ Yurtbaş1, age., s. 50.

${ }^{156}$ Milli Eğitim Bakanlığ 1 , age., s. 202.

${ }^{157}$ Yurtbaş1, age., s. 266.

${ }^{158}$ Yurtbaş1, age., s. 51.

159 Muharrem Ergin, Dede Korkut Kitabı I (Giriş-Metin-Faksimile), AKDTYK Yay. Ankara, 1997, s. 226.

${ }^{160}$ Yurtbaş1, age., s. 266.

161 Aksoy, age., s. 165.
} 


\subsection{Bir Yere Sığamama, Ait Olamama}

Öksüz çocuğun normal davranışlarının dahi yanlış anlaşılabileceği ve herhangi bir yere sığamayacağ1 düşüncesi "Kavun karpuz kökeninde büyür ${ }^{162}$; Kavun kökeninde büyür ${ }^{163}$; Öksüzün ağzı büyük olur doymaz, başı büyük olur eve sığmaz ${ }^{164,}$, şeklinde ifade edilmiştir.

\section{Yapısal İnceleme}

\subsection{Kelime Kuruluşundaki Sözler}

2.1.1. Alıntı kelimeler: "aciyy / āci, arız, bî-peder, hort, kopel, segir, tafal, yetîm, yetîme".

2.1.1.1. Arapçadan alıntılar: "aciyy / āci, arız (Devellioğlu, 2008: 38), seğir (<șagi îr) (Devellioğlu, 2008: 910), tafal (< Ar. tıfl) (Devellioğlu, 2008: 1108), yetîm (< Ar. yetīim) (Devellioğlu, 2008: 1161), yetîme (<Ar. yetime)"'.

2.1.1.2. Farsçadan alıntılar: "bî-peder" (Devellioğlu, 2008: 103)

2.1.1.2.1. Farsça + Türkçe kuruluşunda olan: merdesiz (< Far. merd + T. - siz) (Devellioğlu, 2008: 619)

2.1.1.3. Ermeniceden alıntı: hort (< Erm. hort; Tietze II, 2009: 326; Dankoff, 1995: 67)

2.1.1.3.1. Ermenice + Türkçe kuruluşunda olan: hortlu / hörtlü (<Erm. hort / hört + T. $-l u)$

2.1.1.4. Yunancadan alıntı: kopel (< Yun. kopéli; Tietze II, 2009: 16)

2.1.2. Türkçe Kelimeler: "anasız, atasız, babasız, başsız, çoma, dulaz, ekti, gebe, gebedek, irik, kesit, sevi, tay, teberik, tumbat'”.

2.1.3. Kökeni tespit edilemeyen kelimeler: "cebedak, mesek, milcan, övbet, persin".

2.1.4. Basit kelimeler: "aciyy / āci, arız, bî-peder, cebedak, cemet, çoma, dulaz, ekti, gebe, hıra, hort, irik, kopel, latîm, melkut, mesek, milcan, övbet, persin, segir, sevi, tafal, tay, teberik, tumbat, yetîme".

2.1.5. Türemiş kelimeler: "anasız, atasız, babasız, başsız, bırakıntı, bulduk, buluntu, gebedek, hortlu, kañsız, kesit, meleşmek, merdesiz, öksüz, öksüzlük, yetimlik'”.

\footnotetext{
${ }^{162}$ Aksoy, age., s. 285.

163 Türk Dil Kurumu, Türkçe Sözlük, s. 1359.

${ }^{164}$ Aksoy, age., s. 265.
} 


\subsection{Kelime Grubu Kuruluşundaki Sözler}

2.2.1. İsim fiil kuruluşundakiler: "anasız kalmak'.

2.2.2. Sıfat fiil kuruluşundakiler: "babasız kalasıcık, anasız kalasıca, ellerde illerde kalası, ellere kalası, ellere kalasıca". Bu yapıların -ası sıfat fiil ekiyle kurulduğu ve ilenç mahiyetinde olduğu görülmektedir.

\subsubsection{Sıfat Tamlaması Kuruluşundakiler:}

2.2.3.1. Türkçe sıfat tamlaması: "anasız guzu, keloğlan, saçı bitmedik (yetim), tüyü bitmedik (yetim), yuvasız kuş̧̧uk'.

2.2.3.2. Arapça sıfat tamlaması: "yetîmü't-tarafeyn".

2.2.4. Belirtisiz İsim Tamlaması Kuruluşundakiler: “öksüz anası, öksüz babası, öksüzler babası, anası'”.

2.2.5. Kısaltma Grubu Kuruluşundakiler: "atasız anasız, bağrı geçik, boynu buruk, duluğu sirkeli'.

2.2.6. Birleşik Fiil Grubu Kuruluşundakiler: “öksüz bolmak, öksüz eylemek, öksüz kalmak, öksüz kılmak, taftahlı galmah, yetim bolmak’.

\subsection{Cümle Kuruluşundaki Sözler ${ }^{165}$}

2.3.1. Basit cümleler: "Allah'tan umarım baban öle; Anadan babadan ol; Anadan yetim olasın; Anan baban bir kızll tabutta gide; Anan baban tünbe tünbe ola; Ananın lokmasl ağzına ola; Anan öle; Anasız kal e mi; Anasız kalasın; Anasız kuzu melemez; Atasız uşak (evlat), yularsız eşek gibidir; Baba yüzü görmeyesin; Baban öle; Babanın başucuna oturasın; Babanın lokması ağzına ola; Balaların ardında kala; Balaların ardında meleye; Benim gibi öksüz kalasın; Kavun karpuz kökeninde büyür; Kavun kökeninde büyür; Öksüz çocuğun bağrında yağ olmaz; Öksüz kendi göbeğini kendi keser; Öksüz kır köpeği neyler; Öksüz kuzu toklu olmaz; Öksüz kuzu toplu olmaz; Öksüz oğlan (çocuk), göbeğini kendi keser; Öksüzün alnına güneş doğmaz; Öksüzün başl yerde gerek; Öksüzün büyüğünü döverler; Öksüzün karnı doymaz; Öksüzün öğ̈̈nü birdir; Öksüzün şeytanı çok olur; Öksüzün şeytanı dokuz olur; Öksüzün yüreği yufka olur; Yavruların yetim kala; Yetim kalasın; Yetim kuzu, koç olmaz; Yetim mall, ateşten gömlektir; Yiyeceklerin en kötüsü, yetim malı yemektir; Yuvada çocuğu kalsın'.

${ }^{165}$ Cümlelerin yapı bakımından tasnifinde klasik yöntem benimsenmiştir. 


\subsubsection{Birleşik Cümleler}

2.3.2.1. Girişik birleşik cümleler: "Ana üvey olunca baba gâvur olurmuş; Anadan öksüz, babadan yetim kalanın, yüreği (sırtı) yă̆ bă̆lamaz; Anası olmayanın, babası olmaz; Çiftli çubuklu babam olacağına, gümüş yüzüklü anam olsun; Öksüz büyür büyür küçülür; Yetim hakkl, yedi taşı deler de geçer; Yetim malı gasp edene, hakikât yolu kapalı olur; Yolsuzu yola getirmek, öksüze kaftan giydirmek gibidir; Yüz koyunlu atam kalmaktan, bir yüksüklü anam kalmak yeğdir; Zalime haddini bildirmek, öksüze kaftan biçmek gibidir'’.

2.3.2.2. İç içe birleşik cümleler: "Öksüze güldün mü demişler, "meğer uyurken" demiş; Öksüze vurmuşlar, "vay anam” demiş; Öksüzü dövmüssler, "vay arkam” demiş; Öksüzün karnına vurmuşlar, "vay arkam" demiş; Yetim demiş: "Ben güldüm'. Felek demiş: "Ben neredeydim ?"; Yetime "gel gel" diyen çok da çörek veren olmaz" .

2.3.2.3. Şartlı birleşik cümleler: "Ana, analık olursa baba da babalık olur; Anam olsa da taştan olsa; Öksüz hırsızlı̆̆a çıkarsa ay ilk akşamdan doğar; Öksüz yemek bulsa burnu kanar; Yüz koyunlu atam kalmaktan, bir yüksüklü anam kalmak yeğdir’”.

2.3.3. Sıralı Cümleler: “Alçak eşek binmeye kolay, öksüz çocuk dövmeye kolay; Ana ciğerden yana, baba dağda bir oba; Ana yüreği güveç gibi, baba yüreği bakır tencere gibi kaynarmış; Analı kızın bedeni büyür, anasız kızın sözü; Anasız çocuk evde çürür, babasız çocuk çarşıda; Baba öksüzü, öksüz değil, ana öksüzü, öksüzdür; Babası öksüz, yarım öksüz; anasız öksüz, gerçek öksüz; Eski tutun biti, öksüz oğlanın dili acı olur; Oğlun gibi ever, kızın gibi gelin et; Öksüz neden güler, yanılır da güler; Öksüz oynaşa çıkmış, ay akşamdan doğmuş; Öksüz ölmez, örselenir; Öksüzü kayıran çok, yarım ekmek veren yok; Öksüzün ağzl büyük olur doymaz, başı büyük olur, eve sığmaz; Öksüzün ahı pakçe gelir, yapça kakar; Öksüzün bağrı yanık, gözü sönük olur; Öksüzün bir doyarı ayran, bir doyarı bayram; Öksüzün camide babası, hamamda anası çok olur; Öksüzün dokuz karnı olur, birisi (sekizi) doyar, sekizi (biri) aç gezer; Öksüzün nesi olur, memesiz de büyür; Ölesin, yavrular arkanda kala; Yavşak büyür, bit olur; öksüz büyür, it olur; Yetim büyür, felek utanır; Yetim güler, yanlış güler; Analı oğlak (kuzu), yarda (gökte) oynar (gezer); anasız oğlak (kuzu), yerde oynar (gezer)'.

2.3.4. Bağlı Cümleler: “Anam olsun da duvara ăg kursun; Ha anan ölmüş̧̈ossüzsün, ha baban ölmüş yetimsin; Öksüz doyur da ne yapacağına karışma; Öksüz güler mi gülerse onar mı? Öksüz güler mi meğer yanıla; Öksüz kalasın da beni anasın; Öksüze acır çok ama ekmek verir yok; Öksüzü seven çok olur amma eline beş para veren olmaz; Yetime acıyan çok olur da bir dilim ekmek veren bulunmaz". 


\section{Sonuç:}

1. Orhun Abideleri'nde annesiz anlamıla bir at için, Divanü Lugati't Türk'te yetim, şaşkın anlamında kullanılan öksüz kelimesi bugün Türkiye Türkçesi ağızlarında "ögsüz / öksüs / ösgüz / ösüz / ösüz', şeklinde annesi olmayan çocuk, 'öksüz'” şeklinde anlayışsız (kişi) anlamında kullanılırken, Türkiye Türkçesi yazı dilinde annesi veya babası ya da hem annesi hem babası ölmüş çocuk, çağdaş Türk lehçelerinde ise daha çok yetim karşılığı yani babası ölmüş çocuk için kullanılmaktadır.

2. Öksüz, yetim çocukla ilgili sözlerin daha çok bu çocukların temel ihtiyaçlarının karşılanması, sevgisiz, mutsuz ve bahtsız büyümesiyle ilgili olduğu, temel ihtiyaçların da daha çok '"ekmek" kelimesiyle temsil edildiği görülmüsstür.

3. Sözlerde 69 kez öksüz, 21 kez yetim kelimesi geçmektedir. Öksüz çocukla ilgili sözlerin yetim çocuğa göre çokluğu, çocuk için annesizliğin daha büyük bir acı ve problem olarak algılanmasıyla ilgilidir. '’Babasız öksüz, yarım öksüz; anasız öksüz, gerçek öksüz'’ sözü de bu algiyı yansitır.

4. Öksüz çocuklara yönelik sınırlı sayıdaki olumsuz bakış açısını yansıtan sözler kadir kıymet bilmeme, acı ve kırıcı sözler söyleme ve terbiyeden yoksun büyümeyle ilgilidir.

5. Hak, hukuk bağlamındaki sözlerde yetim çocuğa yönelik kullanımların fazlalı̆̆ı, İslam dininin yetim çocukların haklarına yönelik hassasiyetinin bir yansımasıdır.

6. Öksüzlük ve yetimlik bağlamında 33 kelime (22'si basit, 11'i türemiş), 25 kelime grubu [5 sıfat fiil grubu, 6 sıfat tamlaması (5'i Türkçe, 1'i Arapça), 1 isim fiil grubu, 3 belirtisiz isim tamlaması; 4 kısaltma grubu, 6 birleşik fiil grubu], 101 cümle (45 basit cümle; 25 sıralı cümle, 11 girişik birleşik cümle, 6 iç içe birleşik cümle, 5 şartlı birleşik cümle, 9 bağlı cümle) tespit edilmiştir. Kullanılan 33 kelimenin 7'si Arapçadan, 1'i Farsçadan, 1'i Yunancadan, 1'i Ermeniceden alıntıdır. Tespit edilen 161 sözün 115'i Türkiye Türkçesi döneminden, 15'i tarihî dönem metinlerinden ' Göktürkçe 1, Eski Uygurca 1, Karahanlı Türkçesi 2, Harezm Türkçesi 2, Eski Anadolu Türkçesi 1, Çağatay Türkçesi 1, Osmanlı Türkçesi 7', 31’i Anadolu ağızlarından alınmıştır. 


\section{Kisaltmalar}

AKDTYK: Ankara Üniversitesi Kültür Dil ve Tarih Yüksek Kurumu

TDK: Türk Dil Kurumu

\section{Kaynaklar}

AKALIN, L. S. (1990). Türk Dilek Sözlerinden Alkışlar Kargışlar. Ankara: Kültür Bakanlığ1 Yayınları.

AKSOY, Ö. A. (1971). Atasözleri ve Deyimler Sözlüğ̈̈ I: Atasözleri Sözlügü̈. Ankara: Türk Dil Kurumu Yayınları.

ATA, A. (1997). Kııșașü’l-Enbiyā I (Giriş-Metin-Tıpkıbasım), II (Dizin). Ankara: Türk Dil Kurumu Yayınları.

ATALAY, B. (2006). Divanü Lugati't-Türk Tercümesi I-IV. Ankara: TDK Yayınları.

AYDOĞAN, B. (2010). Mehmet Emin Yurdakul'un Çocuk Şiirleri. Çukurova Üniversitesi Sosyal Bilimler Enstitüsü Dergisi, 19 (2), 120-146.

BULUT, S. (2012). Anadolu Ağızlarında Kullanılan Kalıp Sözler ve Bu Kalıp Sözlerin Kullanım Özellikleri. Turkish Studies, 7 (4), 1117-1155.

CAFEROĞLU, A. (2011). Eski Uygur Türkçesi Sözlüğü. Ankara: Türk Dil Kurumu Yayınları.

DANKOFF, R. (1995). Armenian Loannwords in Turkish. Wiesbaden.

DANKOFF, R. KELLY, J. (1982-1984-1985). Mahmūd al-Kāšgarī: Compendium of the Turkic Dialects I-III (Dīwān lugāt at-Turk) Harward.

DEVELLİĞLU, F. (2008). Osmanlıca-Türkçe Ansiklopedik Lûgat. Ankara: Aydın Yayınları.

ERCiLASUN, A. B. ALIYEV, A. M. vd. (1991). Karşılaştırmalı Türk Lehçeleri Sözlüğü I. Ankara: Kültür Bakanlığı Yayınları.

ERCílASUN, A. B. AKKOYUNLU, Z. (2014). Dîvânu Lugâti’t Türk. Ankara: Türk Dil Kurumu Yayınları.

ERGIN, M. (1997). Dede Korkut Kitabı I (Giriş-Metin-Faksimile). Ankara: Ankara Kültür, Dil ve Tarih Yüksek Kurumu Atatürk Kültür Merkezi Yayınları.

EROL, Ç. (2007). Türkiye Türkçesinde Kalıp Sözler Üzerine Bir İnceleme. Basılmamış Yüksek Lisans Tezi, İstanbul: İstanbul Üniversitesi Sosyal Bilimler Enstitüsü.

ESER, R. E. (2000). Türk Masallarında Çocuk. Basılmamış Yüksek Lisans Tezi, Elazı̆ğ: Fırat Üniversitesi Sosyal Bilimler Enstitüsü.

ERSOYLU, H. (2012). Türk Dilince Dualar Beddualar Sözlüğü. Ankara: Ötüken Yayınlar1.

ERŞAHIN, İ. (1995). Atasözlerimizde Çocuk. Birinci Çocuk Edebiyatı Sempozyumu Bildiriler ve Tartışmalar (23 Nisan 1994). Ankara: Alıç Ofset Yayınları, 139-142.

GÖRKEM, İ. (2001). Türk Edebiyatında Ağıtlar (İnceleme-Metinler). Ankara: Akçağ Yayınları.

HAZAR, M. (2007). Türk Dilinde Çocuk ve Genç. II. Ulusal Çocuk ve Gençlik Edebiyatı Sempozyumu Gelişmeler, Sorunlar ve Çözüm Önerileri (04-06 Ekim 2006). Ankara: Ankara Üniversitesi Eğitim Bilimleri Fakültesi Yayınları, 249-278. 
İLBARS, Z. (1999). Türk Toplumunda Çocuk Anlayışı ve Çocuğa Bakış. II. Ulusal Çocuk Kültürü Kongresi Bildirileri Cumhuriyet ve Çocuk (4-6 Kasım 1998). Ankara: Ankara Üniversitesi Çocuk Kültürü Araştırma ve Uygulama Merkezi Yayınları, 425-429.

İLERİ, C. (2008). Eskişehir İli Mihalıççık ve Yöresi Ağızları. Ankara: Türk Dil Kurumu Yayınlar1.

KALKAN, E. (1998). Afşar Ağıtları. Ankara: Kayseri Büyükşehir Belediyesi Kültür Yayınları.

KARABEYOĞLU, A. R. (2011). Fiillerin Kılınış Hususiyetleri ve -DIk /- DUk İyelik Ekinin Mastar İşlevi. Turkish Studies, 6 (4), 649-658.

KAYA, D. (2001). Folklorumuzda Beddua Söyleme Geleneği ve Türk Halk Şiirinde Beddualar. Ankara: Ankara Kültür, Dil ve Tarih Yüksek Kurumu Atatürk Kültür Merkezi Yayınlar1.

KÖSE, Ü. (2008). İslam Hukuku Açısından Kimsesiz Çocukların Korunması ve Bakımı. Yayımlanmamış Yüksek Lisans Tezi, Kahramanmaraş: Sütçü İmam Üniversitesi Sosyal Bilimler Enstitüsü.

Míldi EĞİTì BAKANLIĞI. (1971). Türk Ata Sözleri ve Deyimleri I- II. İstanbul: Milli Eğitim Bakanlığı Yayınları.

ORKUN, H. N. (1987). Eski Türk Yazıtları I-IV. Ankara: Türk Tarih Kurumu Yayınları.

ÖLMEZ, Z. K. (1996). Ebulgazi Bahadır Han, Şecere-i Terākime (Türkmenlerin Soy Kütüğ̈̈). Ankara: Simurg Yayınları.

TALAT, T. (2010). Orhon Yazıtları. Ankara: TDK Yayınları.

TEZCAN, S. Ve ZÜLFIKAR, H. (2004). Nehcü'l-Ferādis (Cennetlerin Açık Yolu) I (Metin), II (Tipkıbasım). Ankara: Türk Dil Kurumu Yayınları.

TIETZE, A. (2009). Tarihi ve Etimolojik Türkiye Türkçesi Lugatı, C. II (F-J), Sprachgeschichtliches und Etymologisches Wörterbuch des Türkei-Türkischen, Osterreichischen Akademie der Wissenschaften. Wien.

TULUM, M. (2011). XVII. Yüzyıl Türkçesi ve Söz Varlı̆ğ. Ankara: Türk Dil Kurumu Yayınlar1.

TÜRK DİL KURUMU. (1963-1982). Türkiye’de Halk Ağzından Derleme Sözlüğ̈̈ I-XII. Ankara: Türk Dil Kurumu Yayınları.

TÜRK DİL KURUMU. (2011). Türkçe Sözlük. Ankara: Türk Dil Kurumu Yayınları.

ÜLKÜTAŞIR, M. Ş. (1976). Türkiye Türklerinde Ad Verme İle İlgili Gelenek ve İnançlar. $I$. Uluslararası Türk Folklor Kongresi Bildirileri, Ankara: Kültür Bakanlığı Yayınları, IV. Cilt, 369-384.

ÜNLÜ, S. (2012). Harezm Altınordu Türkçesi Sözlüğü. Konya: Eğitim Yayınlanı.

YAVUZ, İ. (2006). Baba Öğ̈̈tleri. Niğde: Tekten Ofset Yayınları.

YAVUZARSLAN, P. (2010). Şemsettin Sami, Kamus-ı Türkî. Ankara: Türk Dil Kurumu Yayınları.

YELTEN, M. (1998). Şirvanlı Mahmud, Târih-i İbn-i Kesîr Tercümesi (Giriş-İnceleme-MetinSözlük). Ankara: Türk Dil Kurumu Yayınları.

YURTBAŞI, M. (2012). Sinıflandırılmış Atasözleri Sözlüğü. İstanbul: Excellence Yayınları.

http://iskilipliyiz.com/forum-oku-59272 oksuz_kimdir.html. 